\title{
NOTES ON THE GEOGRAPHY OF THE BLUE MOUNTAINS AND SYDNEY DISTRICT.
}

\author{
By E. C. Andrews, B.A. \\ (Plates xxxix.-xliv.) \\ INTRODUCTION.
}

The following notes are intended merely as an introduction to the geographical study of the Blue Mountain area. The salient points of the subject only are touched upon, the details being problems for future study. The deductions themselves also are suggestions only, needing more extended inductive studies for confirmation.

For a brief outline of the process involved in stream development, reference may be made to a paper by the writer* on "The Tertiary History of New England," in which the views of the American geographers are epitomised. To Hutton and Playfair, of England, the pioneering of this branch of study is due; but they lived a century in advance of their age, and stream development received little attention for a considerable period after their deaths. Sir A. Geikie recognised the importance of their methods more than half a century later, while J. W. Powell, J. S. Newberry, and others, as the result of exploration in the wonderland of the Western States of America, readily apprehended the natural succession of the forms induced by the agencies of gradation in elevated areas. To the untiring labours of Prof. W. M. Davis and his lucid interpretation of surface forms, modern geography owes probably its greatest impetus. As Prof. Huxley to the theory of biological evolution, so Prof.

\footnotetext{
* Records Geol. Survey N.S. Wales, vii. Pt. 3, 1903, pp. 140-216 (and references).
} 
Davis to geographical studies; and his numerous papers embodied in the publications of Harvard College, The American Journal of Science, the Geographical Magazine, the Geological Survey of the United States and ocher Societies are invaluable to intending workers in this field. The writer also desires to record the great help he has received from the perusal of a paper on "Shoreline Topography" by Dr. F. P. Gulliver* and one of the volumes in the Progressive Science Series on "River Development" by Prof. I. Russell.

In Australian studies very little attention appears to have been bestowed on the importance of appreciating the relative value of various operations known to occur in a cycle, although in a paper on "The Raised Beaches of the Hunter River Delta," by Prof. T. W. E. David and R. Etheridge, Jun., $\uparrow$ the later elevation is differentiated from the earlier and more important subsidence, and to each is assigned its proper share in the coastal topography.

Other workers recognised the operation of contrary movements in the northern division of this State in Extra-Barrier Reef areas. A keen observer like Jukes, $\$$ as the result of inductive studies, recognised undoubted signs of elevation along the Queensland and New South Wales coasts, but condemned his own deductions therefrom as premature inferences because apparently discordant with the conclusions arrived at by the great Darwin for the same place from "Barrier Reef" considerations. The Rev. J. E. T. Woods\| also disputed the ease for elevation, probably on the same grounds.

Other observers of note, however, like Prof. A. Agassiz, Dana, and Rattray, 9 untrammelled by prejudice, recognised the validity

* Proc. Amer. Acad. Arts Sci. xxxiv. No. 8, 1899.

† Rec. Geol. Survey, N.S. Wales, ii. 1890, pp. 37-52, pl. 3.

†. E. Carne, Rec. Geol. Survey N.S. Wales, v. 1897, pp. 71-86.

§ Voyage of H.M.S. "Fly," i.

\| Proc. Linn. Soc. N.S. Wales, v. 1886, pp. 187-189.

T For general references, see E. C. Andrews, Proc. Linn. Soc. N.S. Wales, 1902, Pt. 2, pp. 164.5. 
of the claims of elevation for North Queensland. Yet even workers like these appear to have overlooked what are, in the writer's opinion, the main lessons taught by the shore-line and coastal topography, as also the main criteria of subsidence and late elevation.

In their discussions the idea does not appear to have been entertained of a dominant movement expressing "the algebraic sum " of various slighter movements, viz., that a region might, in a broad sense, represent the overshadowing influence of elevation or subsidence concomitantly with criteria of subsiding coast and shore-line movements in like or contrary directions. To a student of shore-line topography only, the eastern coast of Australia evidences the influence of late elevation at every turn, but to one who gets above these details of beach and coastal plain on to some high sea-cliff, the shore-line and associated areas are seen to be passing through a youthful stage of drowning on which a vibration of recent elevation has been imposed; while to the topographer viewing the coastal sweep from some commanding elevation like the Guy Fawkes "Look Out" in New England, the whole country is seen to be in a state of pronounced uplift interrupted recently (over restricted areas) by slight subsidence and elevation. Thus the high and widely trenched plateau which advances boldly into the sea in North Queensland points to a pronounced cycle of Tertiary elevation, since the initiation of which plateau dissection has advanced to the stage of maturity as regards the coastal area; the long saltwater valleys and boldly seaward advancing headlands, as also the numerous mountainous islands dotting the broad continental shelf, point to a very youthful minor cycle of coastal subsidenee (following on well advanced marine erosion)* which flooded the old baselevelled valleys of the present "cañon cycle," $\dagger$ and allowed of the establishment of the Great Barrier Reef on beds of late Tertiary

* See also Prof. A. Agassiz, "The Great Barrier Reef of Australia." Bull. Mus. Comp. Zool. Harv. Coll. viii.

+ Term adopted after Prof. W. M. Davis. 
age; while upon the same area a still later and comparatively insignificant movement or vibration of elevation has been imposed, criteria of the uplift existing as numerous raised beaches, tombolos and wide coastal plains backed up by high precipitous escarpments.

For the Sydney area we may represent the elevation which attained its maximum importance during the early part of the cañon cycle as 3000 feet, the fluctuating late subsidence as 200 feet, ${ }^{*}$ and the joggle of elevation as 10 feet. The relative importance of each is thus appreciated. In a short time the thin veneer of coastal plain exposed by the elevatory vibration will vanish from the shore-line topography, while under the steady march of marine and subaërial forces the evidence of the epicycle of coastal sinking in late Pleistocene times, although more stable than that of the weaker elevation, will also be found to be shortlived. Yet after their disappearance the geographer will decipher the tale of the great late Tertiary uplift with the greatest ease, though doubtless scores of tremulous movements will modify the topography before the close of the cycle. Care should be exercised not to miss the main lesson in the insignificant details; shore-line, shore, coast, and plateau should be surveyed together, and the recent oscillatory movements discussed in the later portion of this paper may be regarded as ephemeral features which influence the grand issue in part only and depend for the very recognition of their existence on the evidence yielded by the associated sediments, as the occurrence of scaffold planks is inferred from the sight of a finished edifice.

As this paper is written mainly with the object of clearly differentiating between the various divisions of a cycle, let us emphasise the point still further by considering the philosophy of sedimentation as throwing light on the subject. Great systems like our Carboniferous and Permo-Carboniferous show immense

* More pronounced subsidence with equivalent sedimentation is indicated for North Queensland. 
basal conglomerates unconformably overlying finer beds. Other conglomerate and grit beds occur higher up in the series, though subordinate in importance to the great basal examples. Alternating coarse and fine-grained measures, and also bedded and lenticular limestones, occur in the inter-conglomerate spaces. The basal layers of boulders and pebbles argue a pronounced epeirogenic movement accompanied by folding which closed one series of cycles while inaugurating another. During the early stages of the initiatory cycle the torrential action (owing to increased stream grade) of the new streams resulted in great loss of boulders and pebbles along the shore, while the succeeding finer-grained masses evidence the pronounced subjugation of the continuous mountain system. The alternation of coarse and fine layers in vertical succession points to oscillations of movementhere a layer of grit indicating elevation, there a coarse-grained and cross-bedded sandstone evidencing rapid stream-movement, a bed of sandstone or lens of limestone illustrating calm conditions. The occurrence of conglomerates overlying fine sediment or growth as coal seams or mudstones implies the rejuvenescence of elevation succeeding pronounced erosion or slow subsidence and concomitant sedimentation; if the conglomerates be important, a new cycle is demonstrated. Nor must we lose sight of differential and accentuated movements. After elevation, subsidence oscillations act in the direction of diminished erosion and consequently finer sedimentation. A rapid rise after youthful sinking minimises the effect of the drowning. Thus from a consideration of such a system as the Permo-Carboniferous the existence of numerous large and small cycles is proved. Each vibration of movement resulting in a layer of sand or mudstones is overshadowed by the epicycle, each epicycle with its grits, \&c., is dominated by the cycle, which in turn expresses but a fraction of the period.

I desire here to thank Messrs. Dun, Morrison, and Murton for assistance and information supplied in the preparation of this work. 
Thesis.

Several peneplains* were developed at various times at sea-level, and elevated successively to varying heights. The elevations were of the nature of broad vertical uplifts for the centre of the disturbed area, with gradual slopes east and west of the high central plains, the axis of uplift being meridionally disposed. The imperfect reduction of the old plateaus in their central portions permits of the deciphering of the relative amounts of erosion performed during the successive cycles of land-degradation, and thus affords physiographical criteria of the relative duration in time of such geological divisions as the Cretaceous and Tertiary periods.

A study of the Hawkesbury River shows that progressive stream to be the outcome of several periods of stream-revival, during which its original and unimportant consequent direction was succeeded by its present pronounced lengthwise course, as it adjusted itself wonderfully to the surrounding rock structures. The present cañons of the Lower Hawkesbury point to a rejuvenescence of the Pliocene stream, the river incising its way through the differential uplifts along its old course.

The youth of the latest uplift of importance is evidenced by the appearance of the present cañons. The influence of differential erosion on the rock structures is also well seen. An oscillation of subsidence in Pleistocene time is indicated by the conversion of the Pliocene(?) cañons along their lower courses into magnificent harbours, while subsequent stream-action and a very recent vibration of elevation accentuate such features as coastal plainformations.

The commercial significance of the recent drowning and the piracy of the Hawkesbury by beheading of streams, with consequent diminishing of river competence to silt up the harbours, is well seen by a study of the coast.

* One of these may hereafter be referable to "benching" in horizontally bedded strata. 


\section{The Plateaus.}

Standing on some eminence in or around Sydney and looking westward, a range of mountains is seen to present an almost unbroken sky-line to the observer. Here and there a flat-topped mass rises above the general level. The even sky-line represents the stretch of the Blue Mountain plateau, and the still higher table-topped hills count Mount Tomah, Mount King George, Mount Victoria and Blackheath among their number. If a trip be taken across the valley of the Nepean at Penrith to Glenbrook ( 600 feet above sea-level), it will seen that the surface gradually rises until a point is reached almost 3,000 feet above sea-level, when it will be found that numerous large flat-topped masses rise above this level. Crossing one of these mesas, ${ }^{*}$ on which Blackheath and Mount Clarence are situated, a precipitous escarpment is observed to separate the upper and lower plain-like expanses. Thence the 3,000 feet level winds westward, being overshadowed by the mountains possessing subhorizontal summits. Various towns occur on this upland (3,000 feet), among which may be cited Orange, Blayney, Oberon, Hill End, Wattle Flat, Wallerawang and Lithgow. The plain-like expanses are not all at present co-extensive, but were the intervening gullies filled they would form a huge peneplain continuous in all directions and broken only in the central portions by large mountain masses. Around Lawson, Wentworth Falls, and the several towns just enumerated, these higher table-topped hills are common. Blackheath, Mount Victoria, Bell, Mount King George, Mount Tomah and the hills north and north-east of Wallerawang mark points on a higher level which rises some 400 or 500 feet above the lower plateau. Their total area is trifling compared with that of the 3,000 to 3,100 feet level, but were the wide intervening basins filled, they would in turn form another plain some 3,500 feet above sea-level in the central portions. Above these again numerous points occur, flat-topped or cone-shaped, which rise to a height of 4,100

* A flat-topped hill rising above the surrounding plain. 
to 4,300 feet above sea-level. These include the great flat-topped masses east of Bathurst known as the Stony Ridges, the Clear Creek Hills and Mount Horrible; while the Sunny Corner Hills, Mounts Lambie, Walker, Binda and the Jenolan Hills represent points rising to the same level, but more or less dome- or hummockshaped.

Returning to a discussion of the 3,100 feet level, we find that east of a line running north and south in the neighbourhood of Mount Victoria there is a gradual decrease in slope to the sea, varied only by local differences. Thus to Sydney, from Lawson through Glenbrook, the general flat falls gradually to a height of 300 feet at the coast, broken, however, by the great valley of the Nepean at Penrith and the famous monoclinal fold and fault* running north and south through Kurrajong Heights. To the north and north-west of Sydney the general even easterly tilt appears to be bent upwards so as to present a gentle glacis to the metropolitan area. At Hornsby this slope has carried the land to a height of 600 feet above sea-level; beyond this point it spreads horizontally. Standing on the heights above the Hawkesbury River, near Berowra, the surface appears as a plain, surmounted by small flat-topped hills. Southwards from Sydney the 300 feet level rises gently for 40 or 50 miles until the 2,200 feet level is attained, beyond which the surface spreads as a great plain. Numerous small faults and folds will doubtless, hereafter, be found associated with this bent surface.

Throughout the Blue Mountains one finds tremendous gulches or trenches winding among the plateaus. These are bordered by huge parapets or ramparts of sandstone and shale, as much as 1,500 feet high in places. All the clefts end in V-shaped niches, into which waterfalls of great height precipitate themselves. Frequently the bases of the cañons are sunken 2,000 feet below the level of the plateau. Under the sandstone ramparts comes a steep slope of weaker material.

* T. W. E. David, Journ. Proc. Roy. Soc. N.S. Wales, xxxvi., pp. 359-370. 
Fig. 1 is a sketch section across the ordinary type of cañon.

AA represents the high sandstone cliffs, $\mathrm{BB}$ the steep talus slopes. The floors of these valleys, as shown at c, are usually

\section{Fig. 1.}

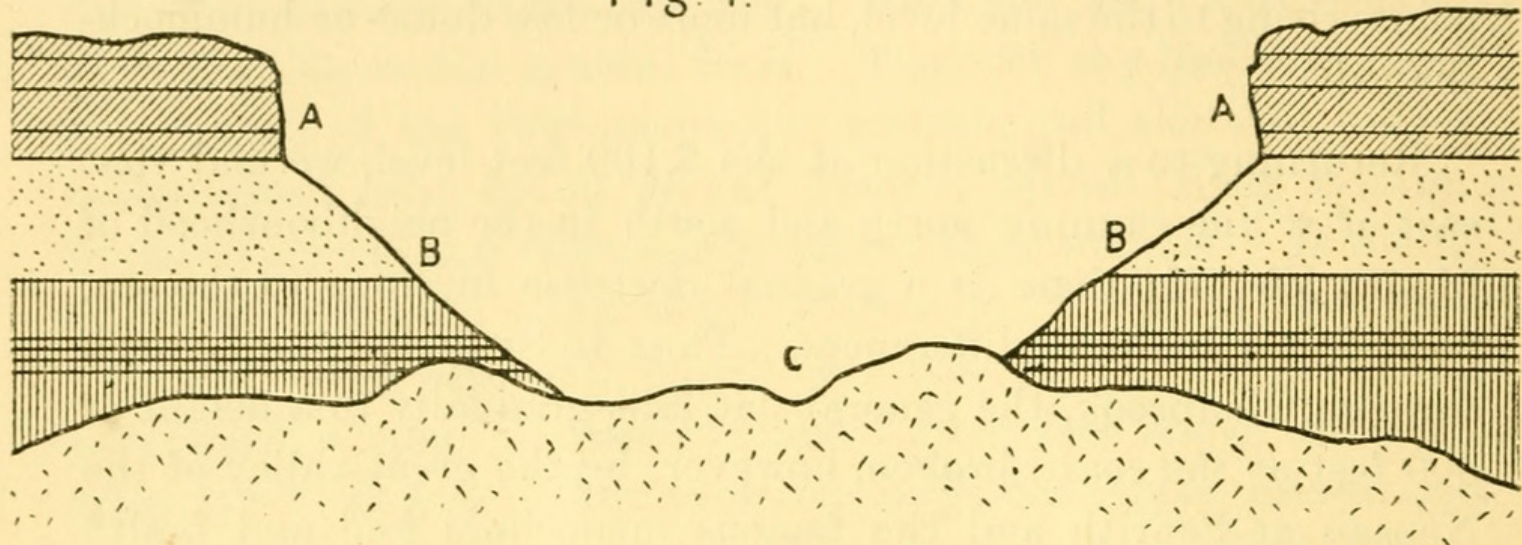

Fig. 1.-Diagram illustrating the formation of the Blue Mountain cañons.

wide. A most interesting feature about them is the fact that if the ordinary slope of one of the sandstone beds as at a be continued across the valley it will coincide with a similar bed in cliff A. Similarly for the shale and sandstone slopes of в and в. ${ }^{*}$ This fact of observation points to the obvious conclusion that at some previous period the sandstone and shale beds must have been continuous across the cañons.

Thus, from the foregoing paragraphs, it will be seen that by filling up all the hollows for each set of flat-topped masses $\dagger$ we shall obtain several plains rising one above the other; the highest being 4,100 or 4,200 feet above sea-level, and of relatively insignificant extent, being represented merely by peaks and a few mesas; the next 3,500 feet above sea-level, represented by long winding mesas; and a still lower one 3,000 or 3,100 feet in absolute height, and of much greater area than the 3,500 feet level. In the case of the 3,100 and 3,500 feet levels we notice that they slope gradually towards sea-level east of a line drawn north and south somewhere between Lithgow and Blackheath,

* C. S. Wilkinson, “Mineral Products of New South Wales,” 1882. 
and towards the interior west of a meridional line passing through Blayney or Orange. To the 3,100 feet level and its coastal slopes we propose the name of the Lithgow Peneplain; to the 3,500 (approximate) fuet level the name of the Blue Mountain Plain.* To the 4,100-4,200 feet level the name Jenolan Plain seems appropriate from the occurrence there of numerous residuals of that old high-level surface. Above the Jenolan level very small hills are found, such as the Sunny Corner Mountain (Plate xxxix).

Fig. $g$ of Plate xxxix represents the relative slopes and mesas of each surface approximately.

More detailed observation may hereafter demand the fusion of the Blue Mountain and Lithgow Plains, with reference of the 3,000 feet level at Lithgow, Bowenfels, Rydal and in the neighbourhoor of Mount King George to "benching" agencies. The great extent of the 3,000 feet surface, however, in the contorted Palæozoic rocks to the near west is against this idea of a common age for the two surfaces.

Thus it would appear that three peneplains have been developed near sea-level, and successively raised 700,400 and 3,100 feet approximately above this datum line. $\dagger$

From a study of the present disposition of the streams we should feel constrained also, even should the evidence of the mesas be withheld, to postulate at least a double cycle of erosion for the area under consideration, so marvellously are the streams adjusted to the rock structures. Reference in detail to this will be made in the proper place. Subaërial erosion and elevation thus appear to be the key to the formation of the successive plateaus.

At present the exact ages of these elevations and the cycles of erosion initiated thereby cannot be fixed. Each cycle, especially

* From the more commonly known peaks in the Blue Mountains which form mesas of this level.

+ Allowance must be made in these figures in the central areas for the incomplete reduction of a plateau to base-level. 
the earliest one, indicates an enormous period of time, and as must be obvious at once, each pronounced cycle such as we have evidence of in this area must be associated with a distinct period of sedimentation such as Tertiary (or Lower and Upper Tertiary), Lower and Upper Cretaceous, Jurassic, etc. Undoubted palæon, tological criteria of age are absent even for the latest movement of elevation resulting in the Lithgow peneplain, although a Miocene $^{*}$ age has been ascribed to the lower high-level plain of Eastern Victoria, which is probably co-extensive through Monaro with the Lithgow peneplain. The evidence as to the age of the Victorian plateau does not, however, appear satisfactory on biological grounds. $\dagger$

It is possible, however, that the Lithgow peneplain was elevated by the diastrophic movement which initiated the earlier Tertiary sedimentation. The writer is inclined to assign this age to the uplift from a consideration of the advanced stage of cañon formation obtaining at present in the plateau surface. No plains have had time to form along the lower river courses, the Hawkesbury being confined to a narrow cañon even near its point of discharge into the sea. Nevertheless wide valleys have been excavated in still more western areas of weakness, while north of Sydney great valley-making is shown as along the lower and middle Hunter River, and the time necessary to excavate cañons in the resistant sandstone of Sydney is very great, and the amount of waste carried into the sea by the wholesale degradation of the Wianamatta Shales farther west is very considerable, being sufficient for the production of thick offshore deposits. The aspect of the Lithgow peneplain at the shore-line also evidences the far-reaching importance of marine erosion, to which a paper will be devoted in the near future. No movement of note has occurred since. Therefore an early Tertiary age for the last great uplift is very probable.

* R. F. Murray, Progress Rep. Geol. Survey, Victoria, No. 5, pp. 96-111.

+ H. Deane, Presidential Address, Proc. Linn. Soc. N.S. Wales, 1895, pp. 652-666. 
It will be shown hereafter, however, that the great Tertiary uplift consisted of two or three distinct upward series of movements. The first one preceded the great basalt period, while another succeeded it, as may be seen by a study of the old river beds.

The formation of the Lithgow Plain occupied, however, a much longer period of time. The latest cycle, which we shall call the "cañon cycie," sufficed for the formation of small valleys only (save in the areas of shales), whereas the former cycle was productive of wide-spread plains continuous in many directions. The time occupied in the formation of the plateau was doubtless many times that comprised in the cañon cycle. Similarly for the formation of the Blue Mountain plain. The earliest formed plain, known as the Jenolan level, had been developed to old age, and indicates a cycle of gradation of such duration in time as to dwarf the times occupied in the succeeding cycles. From these considerations the writer would feel inclined to assign a Lower Cretaceous or Jurassic age for the Jenolan Plain, with an Upper Cretaceous or early Tertiary age for the Lithgow Plain.

Naturally in the study of levels like these, loss to mesas or "inheritances from previous cycles" of erosion during succeeding plateau cycles must not be overlooked. The remnants of one plateau are also attacked during the succeeding cycle of plateau reduction.

Let us imagine that, after a pronounced cycle of erosion in which the resultant mesas represent the most obdurate of the rock structures to erosion, a considerable movement of elevation ensues. Let us also suppose that the rock layers are horizontally disposed or gently inclined and that a soft layer which formerly lay below base level, and therefore beyond the reach of erosive activities, is now revealed by the elevation. During the new cycle the corrading streams will discover the weak layer, and rapid recession of both the weak and overlying strong structures will occur. Should a thick, hard bench occur beneath the soft layer, a terrace will be formed by the removal 
of the upper hard and soft layers until the underlying bench is cut through, the upper surface of the harder layer forming a wide terrace or esplanade. In this way the mesas of a former period may suffer great degradation in the earlier stages of a new cycle, their own powers of resistance to erosion being of no value when "sapping" takes place. Should the rocks be of massive homogeneous nature, as granite, or highly inclined hard rarieties such as indurated slates and quartzites, then, provided the mesas are far removed from the incising action of the revived streams, the younger valleys may attain a considerable width before the residual blocks suffer any appreciable reduction. If the rejuvenated streams flow, however, at the foot of a large mesa, the mass suffers material reduction during cañon development. For example, before the elevation of a plain to form a plateau, an old sluggish river may in its lateral migrations be actually undercutting a large unreduced mass; on revival of the stream by elevation, a cañon quickly becomes the expression of the upward movement, and, as it broadens its valley, the monadnock suffers considerably even during the youthful stages of the cycle. Frequently mesas or buttes are favourably situated for their own preservation, being far removed from strong stream courses after elevation; their very existence, also, after the second cycle of erosion, implies their excessive obduracy of resistance to erosion; lateral corrasion, also, has but little effect on them, since the streams now have forsaken the plains for cañons sunken therein. Thus monadnocks (residuals) occupying the centre of elevation in areas of dense homogeneous rocks will suffer but little until the new cycle of erosion has progressed to such a stage that the main and tributary streams have lowered their courses to a point near base-level and lateral erosion ensues, with consequent broadening of the valleys and concomitant disappearance of the plateau or esplanade encircling the base of the monadnock.

In New England the writer has made special studies of the loss suffered by residuals at the hands of erosive activities. In the granite area of that district may be found remnants of at least four successive cycles of reduction. Only the most siliceous 
residuals of the earlier gradation periods survive to-day, the oldest as peaks, the next in point of age as ridges and subhorizontal masses. Well into the cañon cycle, however, the southern portion of New England was deluged with successive basalt flows.* Alternating hard and weak structures characterised the products of this volcanism; some of the flows were dense and offered great resistance to decay; others, again, by virtue of marked columnar structure and composition, were unstable as shales. The result is that even during such a brief geographical period as the later cañon cycle, the basalts have been "benched" back for many miles in the form of huge terraces, the upper portion of each surviving bench representing the surface (upper) of a hard lava sheet, the material lost to the volcanic rocks during this "terracing" being redistributed by the streams to form the major portion of the extensive "North-west" black-soil plains. The granite mesas and buttes to the north, however, have preserved their outlines in great measure during the whole of the cañon cycle, thus laying claim to being the "survival of the fittest." Loss there has been here decidedly, but confined to the development of shallow valleys by undercutting.

Before the present cycle has advanced to late maturity, the story of the great late Tertiary basalt deluge will survive only in a series of dykes, necks and stray volcanic knobs in the central area. Thus care must ever be exercised in differentiating between monadnocks and later imposed conditions such as recent volcanicity. In all the endurance of residuals is evident:

The enduring quartzites and hard Silurian rocks of which the remnants of the Jenolan Plain consist represent the central and most resistant masses in the Blue Mountain area to the attacks of erosion, for the Jenolan Plain itself evidences a reduction of hard and soft masses alike owing to the length of the cycle. Thus during uplifts which are in the main very similar, the centres of successive elevations being essentially coincident, the

* The relative youth of these flows is demonstrated from the fact that they filled valleys excavated during the cañon cycle. 
Jenolan residuals were always favourably situated as regards their own preservation. During the formation of the Blue Mountain peneplain, the process of "adjustment of streams to structure" had to be started again, but during the Blue Mountain cycle the repeated migrations of the streams had searched out all but the strongest structures. Then in the successive Lithgow Period the loss sustained by these Lambies* was trifling, such wear as they show being expressed by the formation of moderately sized valleys only, their position and hardness allowing of their preservation amid the general destruction. During the cañon cycle a series of deep valleys was carved in the shallow basins of the previous period, mainly as the result of pronounced elevation in forcing underlying weak structures high above sea-level. Examples of these cañoned mesas are the deep gorges at Jenolan and Kowmung (Kanangra) and the Macquarie River Valley, broad in the vicinity of Bathurst and contracted along its lower northern course in a gorge. In the case of the Macquarie River, a dome-shaped mass of granite (suggestively laccolitic in appearance $) \dagger$ is responsible for the weakness, the granite itself being resistant, but the weaker contorted Silurian slates overlying the boss were "stripped off" during the early age of the cañon cycle by the river in its lateral migrations, and these wanderings by discovering the continuation of the weaker rocks underlying the Devonian quartzites of the survivals from the Jenolan denudation, set up sapping, which operated so as to cause the rapid retreat of the precipitous escarpment of the Jenolan mesas at the Stony Ridges and Clear Creek.

\section{The Plateaus.}

1. The Jenolan Plain.--Blue Mountain studies reveal the fact that at some stage in the earth's history - which we have named

* The Americans employ the term "Catoctins" for the unreduced masses in the present cycle, and "Monadnocks" for those of a cycle previous to the present one. The writer proposes the name "Lambies" for the residuals of the third cycle, and "Spiribies" for those of the fourth, from Mts. Lambie and Spiriby, two conspicuous peaks of the Jenolan and Capoompeta levels respectively.

† J. C. Ross, Q.J.G.S., Vol. 50, 1893, pp. 105-119. 
provisionally as Lower Cretaceous or Jurassic-a great plain was developed at sea-level. No idea can be formed in this locality as to the amount of movement initiating the cycle of erosion which resulted in the formation of this plain. Observations conducted in the dense siliceous granites of northern New England, however, show that the Bolivia Plain, consisting of flat-topped masses varying from 4,300 to 4,600 feet in height, resulted from the old age gradation of a plateau about 700-1000 feet in height which had been elevated at the commencement of the cycle. The Jenolan peneplain is approximately the same height as the Bolivia example and is probably its southern extension, although the intervening areas of soft Palæozoic strata have not been able to survive the erosive activities of successive cycles, and thus the relation can be inferred only from the general topographical similarity of the two areas.

The Jenolan period was one of long duration. Cañons had been cut in the plateau, mature valley systems developed; these in turn had expanded into wide plains under the action of lateral corrasion, until, at the close of the cycle, a few rounded eminences (Pl. xxxix., a) only of the most durable Silurian and Devonian rocks remained to attest to the existence of the old upland. The rivers even in flood time pushed loads of silt only beyond their mouths, and doubtless limestones were deposited in the clear water off-shore. Naturally during such a period of stable equilibrium, or rather one in which gradation and the algebraic sum of the elevations and depressions resulted in the formation of a plane near sea-level, the sea had encroached considerably on the land surface. Immediately after the initial elevation it had built up its off-shore base, then it had marched inland, destroying the bars and piling the waste to form the continental shelf. As the bars perished, the land was attacked, and the continental shelf grew at the expense of the coast. Large cliffs were doubtless in this case the expression of youthful sea attacks, but as the coast became subdued by subaërial agencies the cliffs of youth gave place to more subdued forms. As the sea encroached on the land, wave-base became progressively less deeply seated, the sea 
shallowing very gradually for considerable distances from land; thus wave-attack diminished in competency, and in the old age of the cycle the submarine platform and the Jenolan peneplain would almost merge into one another.

At the close of the cycle, then, the Jenolan Plain presented a generally even surface removed but slightly above sea-level (Pl. xxxix., fig. $a$ ) and diversified by gentle hills only; the coast consisted of enormous gently curving beaches unbroken by indentations. Sluggish rivers wandered over the plains, and near their mouths were deflected from their normal consequent courses by the dominant ocean current. The continental shelf was of considerable width, the sea deepening offshore for many miles at an excessively slow rate.

\section{The Blue Mountain Plain (Cretaceous?).}

The further formation of the Jenolan Plain, of which Sunny Corner, the Stony Ridges, the Clear Creek Hills, Mts. Lambie, Binda and Walker are to-day the insignificant remnants, was interrupted by a gentle tilting motion which carried the old plain from sea-level on the east coast to a maximum height of 700 (?) feet in the central portions (Pl. xxxix., fig. $b$ ). A broad central plateau was thus formed, having down-folded east and west limbs. During the previous cycle, and also portion of the Blue Mountain period, the centre of Australia was occupied by a shallow sea, having a portion of its eastern shore in the neighbourhood of Moree, Narrabri and Dubbo. The new area thus secured may have considerably advanced the land eastwards. In that case it consisted essentially of a subaërial plain of denudation, with a marginal plain of marine erosion, capped by off-shore deposits. This capping of sediments would disappear early in the cycle. The Trias-Jura sediments were also exposed somewhat, and subjected to subaërial denudation, although it is probable they came, not into the sphere of pronounced central elevation, but occupied low-pitched east and west limbs only.

It has been suggested that the Blue Mountain Plain is one with the Lithgow level, and that the surface is one of sedimenta- 
tion. The very broad valleys of Lithgow and associated areas, and the 3000 feet level of the western areas appear to be against this view. The writer also predicts differential erosion for the coastal and more inland areas.

The cycle of denudation which closed with the formation of the Blue Mountain peneplain involved the operation of long-continued and slowly acting forces. The streams wore the land down approximately to the old age stage, and broad plains like valleys were induced in all but the central areas of hard Palæozoic rocks (Pl. xxxix., fig. c). Compared with the Jenolan cycle, however, during which the central portions had suffered wholesale reduction, the Blue Mountain cycle was of short duration.

The sequential stages in the coastal topographical development after the uplift, resulted in a set of conditions very similar to those obtaining at the completion of the Jenolan cycle. The sea had, however, less time in which to accomplish its purpose. Thus the encroachment on the land by the sea was less pronounced than in the former gradation period, although the coastal and shore-line features were very similar.

\section{Upper Cretaceous (?) History.}

\section{The Lithgow Plain (The Plateau cycle).}

With the close of the Jenolan and Blue Mountain cycles, the two longest chapters in the modern (geologically considered) topographical development of the Blue Mountain area are ended. The remaining chapters are, however, full of suggestion and interest, inasmuch as minor movements can be read easily in the recent cycles, while the main features alone are decipherable in the Jenolan and Blue Mountain periods, facility of interpretation, as regards surface features, being inversely proportional to the remoteness of time of any cycle of operations under consideration.

While yet the Sunny Corner and associated mountains remained to evidence the former proportions of the Jenolan Plain, another period of elevation occurred, this time, bowever, reaching 
a maximum of some $400 *$ feet only in the central portions. The movement probably did not influence the streams materially, and they immediately commenced to cut narrow cañons near to baselevel in their old wide plains. Fig. $d$ of Pl. xxxix. illustrates the appearance of the tilted Blue Mountain and Jenolan levels. The rocks acted upon during this period were hard, consisting of slates, quartzites and sandstones similar to those around Sydney. Thus river-action was necessarily slow, especially in the final stages.

Stream-action continued for such a period that the eastern plateau as far inland as Wentworth Falls was cut down almost in its entirety to sea-level, mere hillocks being left thence to the coast, as may be seen to-day from the general level surrounding Hornsby and Berowra. In the central plateau, as also the western slopes, the hills had been attacked, and the plains on which Orange, Blayney, Oberon, Wattle Flat, Hill End, Rydal and Lithgow are situated, cut down almost to sea-level (Pl. xxxix., fig. $e)$. Before the period closed the rivers wound and curved endlessly through wide plains of their own making. Every time they marched in serpentine course across the valleys they attacked the bordering hills, and widened their tracks. The channels in the upper portions were filled with excessively rounded pebbles, capped by sand and mud layers. These pebbles consisted of the hardest material only, such as quartz. These old streams, now buried beneath lava flows, evidence oscillatory movements of the plains, a fuller description of which is given in the author's description of New England. $\dagger$

A period of volcanism is shown to be one of the closing events in this cycle. $\neq$ Explosion craters were formed, and long streams

* This broad-bottomed valley near Lithgow, 400 to 500 feet below the Blue Mountain heights, has been assigned by some to benching.

† E. C. Andrews, "An Outline of the Tertiary History of New England," Rec. Geol. Surv. N.S. Wales, vii., Pt. 3, 1903.

\# It is possible, however, that this will be proved to be referable to the later cañon cycle, as in the case of New England. Probably, also, many of the old lava sheets round Bathurst, etc., originated in dykes. 
of basalt poured thence out over the plains, * whereas the great lava plains in New England are suggestive of dyke-aetion. The Hawkesbury all this time had been developing itself at the expense of its neighbours. Originally it was an insignificant stream with a course almost due east to the sea. Thence, however, during the cutting down of the hills it discovered the slightly upturned edges of softer layers of the sandstone capplaces, for instance, in which whole areas of shale existed with sandstone, like that belt of country lying between Penrith and Picton.

Straightway on the discovery it developed a lengthwise course therein, and, pushing its way south, it encountered other consequent or east and west streams. These being unable to cut their way into the surface as quickly as the Hawkesbury, owing to lack of water and load, had their head waters captured by its lengthwise course.

If observations be confined to the eastern portions of the elevated area, localities such as Berowra, Waterfall, Helensburgh, Loddon or Moss Vale, the Lithgow Plain appears to be as completely developed as the older peneplains. Studies conducted in the central areas, however, show that the age of the Lithgow cycle is insignificant compared with the older cycles. Final reduction of the central plateau is the criterion of excessive old age of a cycle of erosion. The Jenolan Plain satisfies this test of senility, and the discrepancy of age between its stage of development and the recent plateau is very pronounced.

\section{The Canon Cycle (Tertiary).}

This period was initiated by pronounced and long continued uplift. This was the great elevation in late geological time (Pl. xxxix., fig. $f$ ). The Lithgow Plain was forced upward until it reached a maximum height of 3,100 feet above the sea in its central portions. The movement was not rapid, but so gradual as to probably occupy very many thousands of years in its completion and not to materially alter the Tertiary (?) river system.

* J. E. Carne, in litt. 
Very probably the old Hawkesbury River bed of Lapstone Hill belonged to the early cañon cycle, and the post-basaltic period of elevation revived the old stream which had previously been flowing over an area of but slight elevation.

The movement was not uniform, since we find on studying the original slopes of the surface (by connecting different portions of the Lithgow Plain across the gullies cut into them during a later period) that :-

1. At Sydney the general surface is 300 feet above sea-level.

2. ,, Hornsby

3. „Glenbrook 600,

600,

4. ", Lithgow, Rydal, and Oberon ,, 3100,

5. ,, Hill End and Wattle Flat , 3000 ,

6. „, Orange and Blayney

6. „, Clifton 2900,

8. „, Kiama Mountains and Moss Vale 2200 ,
,
;
,
,
,
,

,

By following the uppermost beds of the Hawkesbury Sandstone south of Sydney, a splendid idea of the gradual southward rise of the Lithgow Plain is obtained. The heights progressively obtained are, approximately, Sydney 300, Port Hacking 600, Waterfall 700, Helensburgh 900, Bulli Pass 1350, Robertson 2200, and Moss Vale 2200 feet. From all points the observer appears to stand on a limitless plain broken here and there (especially westward) by flat-topped hills.

Thus it appears that there has been an even vertical lift of 3000 feet between Orange and Lithgow, thence towards Sydney a gradual decrease in height, interrupted, however, locally by a large fold and fault, ${ }^{*}$ while northwards and southwards of Sydney the coast has been gradually elevated to maxima of 600 and 2200 feet respectively. Sydney thus occupies the centre of a warped area.

* T. W. E. David, "An important Geological Fault at Kurrajong Heights" (and references). Journ. Proc. Roy. Soc. N.S. Wales, xxxvi., 359. 
From Rydal to Sydney, as also northwards of the latter place to Gosford and southwards to Illawarra, the upper portion of this great sweep of the Lithgow Plain consists of hard layers of sandstone, 900 feet thick at Sydney but thinning away rapidly thence to the north, west and south. The greater portion of the area between Sydney, Parramatta, Penrith, Glenbrook, Camden and Picton is composed of layers of soft sandstone and shales, thus forming an extremely weak spot in a very hard setting. Again, the hard cap of sandstone overlies other sandstones, sandwiched in with layers of shales, coal seams, etc., the whole forming a very weak structure when once the hard protecting cap has been removed. The rock structures west of Rydal are, in places, excessively strong, consisting of indurated silurian slates and Devonian quartzites.

Fig. $e$ of Pl. xxxix. represents the original appearance of the Lithgow Plain before the cañon cycle, with the flat-topped masses of the Blue Mountain and Jenolan Plains rising above it. The rock structure is also shown approximately, explaining the reason why the soft underlying shales were not attacked during this period.

Fig. $f$ of Pl. xxxix. represents the uplift of this plain for 3000 feet above sea-level, and the relation of its structures now shows that at some little distance inland the weak shales and sandstones outcrop high above sea-level, while east of Glenbrook they are still below that level.

To digress slightly, it will be seen from a glance at the diagrams that the hills to the east and west of the central portions were never so large as those of the centre itself :-

(1.) Since the elevations were not so pronounced on the marginal or coastal portions as in the central areas.

(2.) Owing to increased river-action on the marginal areas (the whole of the drainage acting there) the result being that broad valleys are there developed by lateral corrasion, while the cañons of the central plateau are in their infancy.

Thus in all these cycles of gradation we should expect the mountains (unless extremely resistant) away from the central 
portions to disappear first, and great plains to exist in their place, while considerable flat-topped masses occupy almost the whole of the centre.*

To return to the discussion of the elevation, we note that the streams received a marked impetus therefrom. Instead of winding as heretofore sluggishly over the wide Lithgow Plain, they cascaded furiously to the sea and proceeded to entrench themselves in their old basins. They would also be confined to steep narrow cañons until they could saw their way through the hard overlying sandstone. As the consequent Hawkesbury cut its way through the resistant sandstone layer between Richmond and Broken Bay, so the soft layers of shale between Penrith and Picton were rapidly attacked by the lengthwise course of the river. It could, however, only cut downwards through the shales as quickly as the hard sandstone allowed the lower portion of the river to sink through its mass; thus the subsequent Hawkesbury amused itself meanwhile with meandering across the soft layers, scooping them out for miles in its migrations. The old plateau (Miocene?) stream once flowed through Glenbrook, traces of which survive in the large conglomerates occurring there. The stream at that period doubtless ran at a point but slightly above sea-level, 600 feet below its present position. Traces of lower levels may be seen in the cuttings between Penrith and Glenbrook and on the large flat at St. Mary's. $\dagger$

The cañon cycle was the period of exultation for the Hawkesbury. During the previous period it had searched out the weak spots then above sea-level and had developed its subsequent course in great measure, capturing the smaller consequent streams as they were unable to cut their cañons fast enough into the hard eastern layers. The Nepean appears to have been captured in this manner, and as we now know it is thus an obsequent stream.

* E. C. Andrews, "An outline of the Tertiary History of New England" (and references). Rec. Geol. Surv. N.S. Wales, vii, 1903.

+ W. B. Clarke, Sedimentary Formations of New South Wales. 4th Edition, and map. 
The insignificant remnants of these so captured or beheaded streams, determined* in the previous cycle and modified in the cañon period, are known as George's, Port Hacking and Cook's Rivers and the greater number of the streams of the Illawarra coast.

Although, as was mentioned previously, (a statement to be amplified later) the very gradual uplift of the Lithgow Plain allowed the Hawkesbury to entrench itself along its former valley, it is natural to postulate decided stream-modifications for the cañon cycle, the following structures being competent to originate such modifications :-

(a) The fold and fault passing through Glenbrook and Kurrajong.

(b) The Wianamatta Shales of the Penrith-Picton area.

(c) The great warp-like elevation.

(d) The elevation of soft shales and other strata to a point considerably above sea-level.

The fold and associated fault have been described in some detail by Prof. T. W. E. David $\uparrow$. The author, from topographical criteria, is inclined to assign also a considerable age for these movements. By some the fold has been considered as the movement which drowned the coastal valleys in late Pleistocene time. In these earlier discussions the evidence yielded by cañon cycle erosion appears to have been overlooked. Later observations\$ prove the plateau to have passed through a great phase of degradation since the slow movements resulting in the fold and later fault. A considerable time appears evident for the movement because of the opposite pitches shown, illustrating the slow

* (a) From a consideration of their present channels, which are suited to their size. (b) Such admirable adjustment of streams to structure as shown here is the work of more than one cycle.

+ "An Important Geological Fault at Kurrajong Heights, N.S. Wales." Journ. Proc. Roy. Soc. N.S. Wales, xxxvi. pp. 359-370 (and references).

+ C. S. Wiikinson.

§ T. W. E. David, op. cit. p. 365. 
adjustment of coastal masses to one set of conditions and later reversal of the motion. The fold and fault appear to date back at least to the closing stages of the plateau (Lithgow) cycle. The establishment of the old plain stream, before the cañon cycle commenced, along a line fairly coincident with the general direction taken by the great fold, would at first sight appear to throw the age of the movement back well into the plateau cycle, on the ground that the fault line predetermined the river course rather than that the fault followed the stream. The Wianamatta Shales themselves, however, by their position appear competent to bring about such stream-deflection, and until further observations are taken along the line of folding and faulting the writer would be inclined to refer the age of the movements to the early cañon stage, ${ }^{*}$ and assign the prime cause of the longitudinal course of the river to the instability of the shales and the prevailing rock strike. A fine problem for future study is thus opened up, viz., as to the relative age of river and folding, for faults rarely assume accidental parallelism with streams.

Possibly the movement described by Prof. David $\dagger$ may be but a fresh slip on an ancient line of fault, but it seems absolutely demonstrated, however, that the fault scarp as seen to-day does not antedate the cañon cycle. River-development must be the criterion of age in the present state of our knowledge.

On the other hand, assuming the age of the folding to postdate the plateau cycle, it appears that the subsequent Hawkesbury had practically determined its course before the folding took place; thus the influence of the fold would not be marked, though its guiding action appears manifest in places.

The Wianamatta Shales are doubtless responsible in great measure for the lengthwise course of the river. On the great

* Very probably the old Hawkesbury River bed of Lapstone Hill belonged to the early cañon cycle, and the post-basaltic period of elevation revived the old stream which had previously been flowing over an area of but slight elevation. 
Tertiary deformation they kept the stream within their area, while allowing great freedom of lateral movement.

The deformation which characterised the uplift doubtless modified some of the beheaded streams, as also headwater corrasion, although, as will shortly be shown, an excessively slow movement is evidenced for the elevation, thus reducing the competence of gravity as a deviating agent to a minimum.

The significance of a weak series underlying a hard shell beneath base-level during the plateau cycles, and raised thousands of feet above that datum surface in the cañon period, cannot be overestimated in stream modification. After the initial movements of uplift the upper streams kept gnawing their way back into the sandstone, forming deep cañons therein, with alcoves and recesses branching off from the main valleys, while waterfalls occupied the receding niches in the walls of masonry. Some little distance west of Penrith the gradual tilting of the surface had caused the underlying shales to be exposed by the incising streams. This discovery by the streams was the signal for a marked change in valley-making. Instantly "sapping" was set up, the soft shales were washed out by vertical and lateral cutting, the weight and great vertical joints of the overlying sandstone causing it to fracture and fall in wholesale manner, and a wondrous recession of the cañon walls took place, the $\mathrm{V}$-shaped trenches opening out into very broad valleys. The upper cliffs now altered their steeply sloping attitude to great vertical ramparts (Pl. xl.). Yet along their lower courses the aggregated waters of the Hawkesbury streams are still forced to occupy steep narrow channels only, since the soft underlying shales here lie below base-level, and the cañon cycle is not of sufficient age to have allowed the streams to form wide valleys in the hard sandstone. Thus the upper streams of the Wollondilly, Cox and Capertee valleys occupy broad cañons, which open out lower down into the main stream by mere "gaps."* The Hawkesbury itself

* For a fuller description of the philosophy of this mixture of "iron and clay" structures, see Memoirs of Geological Survey of N.S. Wales. Geology. Vol. 3, pp. 115-120 (J. E. Carne, F.G.S.). 
from Wiseman's Ferry to Sydney is a narrow gorge sunken into the Lithgow Plain and bordered by monstrous precipices. Every particle of material lost to the plateau by the formation of the mountain valleys has had to pass through the narrow defile of the Lower Hawkesbury to the sea.

Interesting in this connection, also, is the choice of course adopted by the Hawkesbury below Penrith, where its path is a cañon sunken in a plateau about 700 feet in height, while the short track to the sea from Penrith lies through a plateau only 300 feet above sea-level and composed in the main of soft shales.

This Lower Hawkesbury course, then, teaches four most important lessons :-

(1). That the river sawed its way through the coastal sandstone as the land was warped athwart its course, otherwise, instead of wandering 50 miles out of its way to attack a dense, hard plateau overtopping the surrounding eastern areas, it would have been forced under stress of gravity to take the line of steepest descent over the deformed area to the sea, viz., by way of Sydney, where the warping was but 300 feet above sea-level.

(2). The Hawkesbury is thus seen to be a revived stream, whose piratical tendencies had practically determined its present direction of flow in the preceding plateau cycle.

The wonderful "adjustment of streams to structure" (to employ a phrase used by Prof. W. M. Davis) in the case of this stream also points to at least a double cycle of subaërial erosion. A glance at any good map will make this clear to students of topography, especially if examined in connection with its piracy of the Shoalhaven River.

(3). The excessively resistant nature of the upper sandstone layer as compared with the underlying soft beds.

(4). The excessive youth of the cañon cycle as compared with the time occupied in the formation of the Lithgow peneplain, for in the plateau cycle great areas of hard sandstone and quartzite had been cut away to sea-level, whereas cañons only express the loss suffered since the last great uplift. Untrained minds would be liable to be overawed by the tale of erosion as revealed by a 
review of the tremendous gulches of the cañon cycle and would see nothing phenomenal in the sluggish meanderings of a great river flowing over a broad plain at sea-level. Yet in the latter case the great plateau which gave birth to the stream has entirely vanished from the field, while the gorgeous cañons (Plate xli.) incised in the high lands to-day evidence the mere start of those activities which in the case of the plain have completely removed the towering mountains from the landscape, involving in its accomplishment the passage of untold years.

Another important lesson will be dwelt upon when discussing the origin of Sydney Harbour.

Sydney Harbour, Botany Bay, the Parramatta River and Port Hacking represent valleys cut in the sandstone by small streams. * They had no large bodies of water with which to develop broad flood plains, and contented themselves with excavating small branching valleys, broadening here and there, as at Botany and Botany Bay, where soft layers of rock and shale were discovered.

At this period, when the cañon cycle had progressed so far that the rivers presented essentially the same features as they possess to-day, (Plate xxxix., fig. $g$ ) the coast-line contained no harbours, for, to retrace our steps to the close of the previous plateau cycle, we shall see that the Tertiary uplift had operated so as to drown the old shore-line, and a long unroughened coastline was initiated, the warping of the old plain causing the shoreline to take on the appearance of a huge embayment. The waves soon began cutting in close to the land, at the same time building in the waste below wave-base to form the continental delta. Cliffs were formed in the hard sandstone, and shoals and forelands then for a period protected the land. Afterwards the sea encroached still further, and great cliffs became the expression of the later attack of the sea on the coast. All this time the streams had quietly been cutting their way into the smooth uplifted plain, and from the first mild roughening of the surface

* A study of their valleys points to the conclusion that they are rejuvenated streams in part, which had been beheaded in the plateau cycle.

52 
they had gradually cut a host of valleys to base-level along their lower courses. The coast may at this advanced period of marine erosion be considered from two standpoints: firstly, as being minutely irregular; secondly, as being broadly very regular. The latter is the result of long-continued marine erosion, the former as being due to the action of streams on weak structures. A regular network of dykes exists in the Sydney sandstones, and these quickly became guiding lines for streamlets. The larger irregularities were the cañons of the George's, Parramatta, and Hawkesbury Rivers.

A measure of the amount of shoaling for the shore of this period is supplied by a calculation of the amount of material lost to the mountains by the excavation therein of valleys such as those of the Hawkesbury and its tributaries.

\section{Post-Tertiary Subsidence.}

After corrasion had reached the stage when the coast-line was regular and harbourless, and the numerous streams discharged into the shallow sea at the shore-line, the coast and shore began to sink very gradually, the sea trespassed over the sandy shoals and ran far into the drowned river valleys, converting them into magnificent harbours (Plates xlii.-xliii.). The movement was differential, and probably resulted in a slight elevation for the central areas. Rivers like the Hawkesbury had cut their channels down almost to base-level for long distances, yet the sea trespassed over such areas only. At various points along the shore-line or thereabouts an estimate can be obtained of the amount of drowning. At Peat's Ferry, where the river originally flowed at sealevel, the depth of the old valley floor below the present waterway would give the amount of subsidence at that point. The amount of drowning was probably about 200 feet in the neighbourhood of the shore-line.*

Sydney Harbour was formed by the drowning and betrunking of the Parramatta and Lane Cove Creeks. North and South

* T. W. E. David, Journ. Proc. Roy. Soc. N.S. Wales, xxx. 1896, p. 57. 
Heads were also converted into islands by the sinking, sea passages existing at Manly and Bondi. Brisbane Water, Broken Bay, Botany Bay and Port Hacking (Plate xliii.) were also formed by the drowning of the Hawkesbury, George's, and Hacking Rivers. The tiny cañons excavated in the weak coast spots by the streams were also converted into such inlets as Bronte and Maroubra.

This movement of subsidence is very youthful, since the main streams present the same appearance as they possessed immediately prior to the sinking, all the salient features of the valleys being determined in the earlier stages of the cañon cycle.

The movement appears to have been completed for a considerable period, as is evidenced by the characteristic bay bars of the coast between Port Hacking and Broken Bay. These bay bars will be more fully described when discussing the vibration of elevation which succeeded the oscillation of subsidence.

The rivers, however, still sent down their loads of sand and mud, and thus commenced to fill up the magnificent series of harbours formed by the drowning. The floods of the Hawkesbury silted up the lower salt-water channel, probably possessing, in the earlier stages of drowning, over a hundred feet of water. The dominant currents also swept the river loads and cliff débris into sheltered spots to form wide shoals.

The sinking of the shore-line allowed the sea to advance and rapidly undermine the cliffs. The movement is still youthful, as may be seen by a study of the cliffs between Port Jackson and Botany Bay, where the 250 feet walls end abruptly in 8 to 10 fathoms of water, thus showing that the formation of forelands and beaches in that locality is still distant in point of time.

\section{Recent Elevation.}

After the partial shoaling up of salt-water arms like Broken and Botany Bays a slight movement or vibration of elevation ensued for the coast. In the Sydney district its vertical range along the shore-line probably did not exceed 10 or 15 feet. Its effect was to convert into dry land the shoals formed by the tide 
and current action in the previous oscillation of subsidence. The movement is extremely recent, even historically considered, since very little changes have been effected by the streams even on the raised flats (coastal plains) of incoherent sand. Probably 100 or 200 years would embrace the period of time since the movement.

A brief description of several portions of the shore-line of Sydney will illustrate the significance of the recent subsidence and much more recent uplift, and furnish an explanation of some of the most interesting topographical features of the sea-margin.

(a) Dominant Wind and Current.-Let $\mathrm{B}$ represent the dominant wind of any region, the dominant current is shown

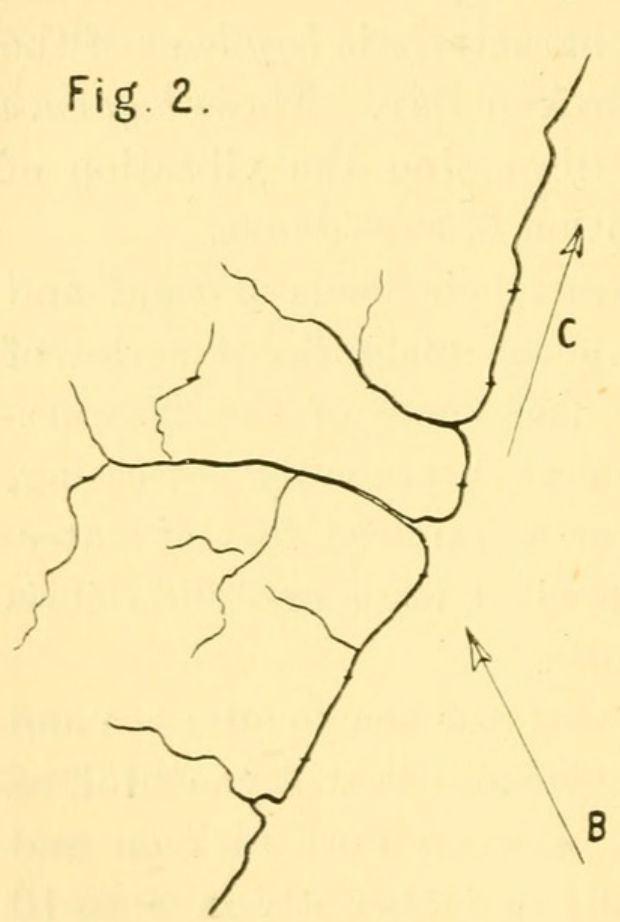
for the coast by the arrow $\mathrm{C}$ acting in the larger angle made by the course of the wind with the shoreline. This wind appears to be from the south-south-east, near Sydney, as evidenced by the general direction which the sand dunes of Kronulla, Lady Robinson's Beach and Bondi incline, or the prevailing inclination of the vegetation on the exposed headlands. Prevailingand dominant currents must not be confused. A current may set from the north for B nine months in the year and yet not accomplish a tithe of the work

Fig. 2.--Diagram illustrating accomplished by one acting fiercely dominant wind and resulting from the south during the remaining dominant current.

three months, since work performed varies as the sixth power of the current velocity. Thus, if a current from the north perform a certain work, a current from the south moving at three times the velocity will perform 729 times the task of the weaker current. In this connection also must be considered the work performed by waves during severe storms. 
(b) Bondi-_-During the Post-Tertiary oscillation of subsidence South Head was converted into an island, a long passage connecting sea and harbour by way of Bondi and Rose Bay. The dominant along-shore current brought sand and waste lost to the Waverley cliffs into the gap; and a bar was quickly formed in the passage. The dominant wind has free play at Bondi, and the bar was quickly piled up above the waves by the heavy wind. Several old shore-lines were formed in this way as the bar grew seawards, with shallow troughs between the old beaches. Silting took place in the blocked passage on the harbour side, and in course of time a shoal was formed above water at low tide. The recent movement of elevation converted the shoals and shorelines into dry land, and the dominant southerly wind piled up huge sand dunes on the former beach-lines and shoals.

It is probable that the sea is even now encroaching on its former work. In that case peat or allied material which once grew in the troughs between the successive shore-lines will be exposed on the beach during storms.

An interesting problem in structure is suggested by a study of Bondi. The underlying sand masses represent tide and marine current action; the long curving and now buried beach-lines represent wind-action; while the present masses of sand dunes under which the marine sediments are buried also are windblown. It may be possible that many areas in the Hawkesbury Sandstone may represent closely related sea and wind action. The writer intends to present a short note in the near future on the structure of the Triassic Sandstones of Sydney.

(c) Manly.-North Head also was converted into an island during the recent movement of subsidence. As for the present flat on which Manly is situated, it will be evident at once that its seaward aspect does not face the dominant wind, and that it is screened also in great measure from it as it sweeps across the harbour.

The heavy waves battered North Head, and produced great quantities of sand, which were swept northwards by the dominant current. In a minor degree also the gentler current from the 
north brought sand into the area under consideration. The Manly Channel formed a quiet spot where the currents had little power. Thus a great deal of the loss to the cliffs by marine erosion, and to the neighbouring land surfaces by streams, fell away from the centre current, and was deposited to form a shoal at low tide in the passage. Wave-action was not strongly marked. In course of time a shoal grew across the channel. At high tides the shoal would be completely covered, while in times of dead low spring tides the greater portion of the shoal would possibly be converted into dry land, and a narrow channel only connect sea and harbour together at the gap. The recent elevation carried the shoal some 10 feet higher, thus converting it into dry land, in which, however, a slight tidal channel would still exist. Marine erosion, dominant current, tide and elevation are thus the key to the origin of Manly.

The coastal plain continuous with the Manly flat had a similar origin, although here the dominant wind had some play, and the conditions are at times similar to those obtaining at Bondi. A couple of small creeks were dammed back by bay bars, and the lagoons thus formed were silted up in part. The recent vibration of elevation converted these into flats above the reach of the highest tides.

Such an island, as North Head, tied to the mainland by a sand bar or flat is called a "tombolo."*

Mr. L. Gundlach, Civil Enginner, informs me that Manly flat is composed of sand for at least 16 feet below the present surface, as revealed by sewage excavations.

(d) Sydney Harbour. - Had the Hawkesbury outletted in the vicinity of Botany Bay or Port Hacking, the enormous amount of débris carried out to sea in times of flood would be borne along shore by the dominant north current and deposited between the Heads in part as being a place of slight current. Thus the

* F. P. Gulliver, "Shoreline Topography." Proc. Am. Acad. Arts and Sci. xxxiv., 1899. 
entrance to the Harbour would have been speedily blocked up as the Manly Channel has already become.

(2). The products of marine erosion will in time to come be borne along shore from the cliffs between Sydney Harbour and Botany Bay, and distributed to form a huge wing-like bar curving north and west from South Head. Beaches also will probably then exist under the cliffs.

(3). The streams which flow into Port Jackson are insignificant (owing to the former piracy by the Hawkesbury), and possess very little loads in time of flood. The action of these tiny streams will be to gradually silt up their own salt-water channels first, the time being far away when they can seriously affect harbour navigation.

(4). It will be remembered that the Hawkesbury developed a lengthwise course which, running north and south but a short distance west of Sydney, captured the headwaters of the other consequent streams. Here then we see the beneficial effects of this stream piracy on the commercial aspect of Sydney Harbour, since otherwise its streams would be possessed of considerable loads, the action of which would be to rapidly silt up the waterway.

Thus, briefly, it owes its importance to its steep off-shores, and the absence of considerable streams discharging either into it or into the sea immediately to the south.

(e) Botany Bay.-The huge sand flats and dunes skirting this bay are additional instances of the operation of forces discussed in connection with Sydney Harbour.

1. Kronulla Beach faces the dominant wind, and encroachment on the bay is shown by the rapid accumulation of huge sand dunes during south-east storms.

2. Lady Robinson's Beach is a magnificent example of a series of parallel bay-bars formed at the head of the bay. During the movement of subsidence the waste brought down by George's and Cook's Rivers, as also in large measure that swept into the bay by along-shore transportation, silted up the bay in part, and 
allowed the heavy waves coming in through the Botany Heads to form a great sand bar about 1,000 yards inland of the present Lady Robinson's Beach. On this sand-bar formed by the heavy waves and about six miles in length the wind piled up sand to form a beach seaward of the original shore-line, and separated thence by a lagoon from 300 to 600 yards in width. The flat drained by the present Muddy Creek indicates the site of this old lagoon. As more material was swept into the bay, the bar grew off-shore, and another beach was piled up by the winds. Thus two great curving parallel bars were formed, separated by a long shallow trough. Many times this action was repeated until a whole series of sympathetically curving bars (beaches) with rounded tops and long rolling troughs were formed, and totalling about 1,000 yards in width (Plate xliv.). The crests are several miles in length, and the intervening troughs are from 6 to 15 feet lower. Doubtless peaty growths will be found in various places under the surface, representing marshy conditions of the inter-beach areas. The shape of the beaches indicates bottom action, the horns giving it a symmetrical concave aspect to the heavier seas, along-shore transportation being negligible.

Subsequently to this formation came the very late elevation of some 10 feet, and the series of sand bars and associated trough areas became dry land.

Another bar is now forming at a short distance off-shore. As time advances Muddy Creek will become dry land-in fact it has adranced partly to that stage from the lagoon marsh meadow by draining.

3. Shea's Creek.-This, as has been shown in detail by Prof. T. W. E. David and R. Etheridge, Junr., ${ }^{*}$ evidences the action of the recent oscillation of subsidence. Botany Bay, as shown by their map, formerly extended to Redfern, but shoaling ensued, and the recent elevation converted the shoals to dry land and mud flats. These flats represent the shoaling of quieter waters,

*Journ. Proc. Roy. Soc. N.S. Wales, xxx., 1896, pp. 158-185. 
contrasted with the conditions obtaining simultaneously at Lady Robinson's Beach.

(f) The Hawkesbury River.-Visitors to Gosford will remember that the train travels for nearly a mile and a half over a sand-flat as Woy Woy is approached. It is raised a few feet only above sea-level, is composed of sand, and contains many thousands of shells in its upper portions exactly similar to those occurring in the associated waters. The surface is not irregular like those sand heaps piled up by winds, or those formed by heavy waters and winds as at Lady Robinson's Beach. There are also, in this secluded spot, no waves competent to pile up sand-bars, nor streams capable of forming deltas high above sea-level.

When the oscillation of subsidence occurred which converted the Lower Hawesbury and its branches into salt-water bays, the loads of sand and silt still brought down from the Blue Mountains and Goulburn River District by the floods were partly swept out to sea along the main channel, and partly deposited by the lagging current in the sheltered arms of the river. Débris also was brought down from the neighbouring hills by the streams entering from about Gosford and Woy Woy, and rearranged by the tides to form wide shoals in the quieter spots, on which, as they approached the surface, whole hosts of shells grew. A slight movement of elevation then converted these shell-flats into dry land habitable by man.

A similar explanation accounts for the great flats skirting Lake Macquarie, and crossed on their western margins by the Newcastle trains.

(g) Narrabeen, Rock Lily, Dee Why and Curl Curl Lagoons.-Plate xliv., supplied by Mr. M. Morrison, illustrates the general appearance of this portion of the coast. To understand the successive stages of growth, we must refer to the activities in operation since the initiation of the cañon cycle. The general uplift which resulted in a warp for the Sydney area probably submerged the old coast-line of the Lithgow plain, as is evidenced 
by the peculiar character of the topography. ${ }^{*}$ During the Lithgow cycle the rivers had pushed their loads off-shore, and the sea currents had built them into the smooth continental shelf below wave-attack. A wide sloping shelf was thus brought about at the close of the period, and the sedimentation on that shelf was more deeply buried by the warping. During the period between the birth of the cañon cycle and the recent drowning the rivers sent down huge loads of waste from the highlands, which were redistributed by the sea to furnish another coat to the already smooth off-shore deposits of the plateau cycle. At the same time the sea rapidly encroached on the coastal strip, the land retreating until huge cliffs were formed. A measure of the amount of this sea-attack is difficult to arrive at, as the land slope is irregularnow gently convex and now concave to the sky-and does not represent an even inclination seawards near Sydney. $\dot{\dagger}$. In any case a considerable encroachment is indicated by an attempted restoration of the old slopes, probably exceeding 10 miles in width. $\ddagger$

A large fault appears to be indicated for the Nowra District. On the south of the Shoalhaven River, the Lithgow Plain rises

* If we assume that the warping induced elevation over the coast-line of the plateau cycle, then we are forced to one of two conclusions from the evidence of the topography:--

(1) Either the cover of marine (off-shore) deposits laid down on the shore of the plateau period and now forming the plateau around Berowra, Sydney, and Illawarra has been completely removed during the cañon cycle, and that too in certain places where such sediment would be particularly favourably situated as regards preservation; and moreover, from a consideration of such presumably stripped areas, the off-shore base must have been very regular.

(2) Or (assuming that the present coastal plateau is not of marine erosion) marine erosion in the cañon cycle has allowed the sea to considerably encroach on the elevated area, eating it back beyond the limits of the "plateau cycle" shore-line.

† Ante, p. 789.

+ Consider, for example, the effect of marine erosion in the neighbourhood of Illawarra. Here the waves have cut the land down from nothing at the shore-line in early cañon cycle times to escarpments 2,000 feet in height near the present shore-line, the late elevation causing the sea to retreat considerably. Here again we have a measure of the great age of the cañon cycle. 
gradually from near sea-level to a height of over 2,000 feet some 30 miles in a westerly and south-westerly direction, while immediately to the north, across the Shoalhaven, rises the great escarpment of the Lithgow Plain some 2,000 feet in height.

By the removal of the land waste, the former smooth and later warped plain was roughened into valleys and ridges, reduction almost to base-level occurring along the lower stream courses. The recent subsidence converted these valleys to bays and harbours, as explained earlier in these notes. The sea dashing into bays of open type like the original Narrabeen and Rock Lily indents formed huge bars across their entrances, and impounded the inner waters to form lagoons. Bars $\ddagger$ of the Narrabeen type show several aggradational lines of beach-growth according to the observations of Mr. M. Morrison and myself. In all cases the influence of a dominant current from the south is inferred from the occurrence of wedge-shaped bars attached by their bases to headlands forming the southern boundaries of the indents, while their northern ends are free, the lagoon outlets being in all cases jammed closely up to the headlands on the northern aspect of the lagoons. No dominant overlaps occur, however, bottom action being more pronounced. With the formation of the lagoons the force of the sea was able more rapidly to steepen the shore-slope instead of being fruitlessly expended in the smooth waters of an inlet. The waste brought down by the coastal streams and the sand blown over the bar by the dominant wind were now carried into the lagoons and redistributed by the tides to form shoals. Before complete silting up ensued the recent vibration of elevation occurred, and the old bays were transformed into huge flats, backed up by high broad belts of sand dunes (beaches), with small residual lagoons representing the still unshoaled portions. Sequential stages in the shore-line topography will be the complete filling of the lagoons, the formation

$\mp$ The explanation of the cause of these bay bars will be dealt with in a future note on the submarine platform of New South Wales. Along-shore currents, combined with maximum wave action to form a steepening of the shore by accumulation, is doubtless the explanation. 
of other bars and beaches further off-shore, and then the steady march inland of the sea with destruction of the present bars, beaches and lagoon-meadows, concomitantly with the gradual reduction of the neighbouring and distant hills by the forces of subaërial erosion.

All these points can be clearly made out by the observer from the Sydney cliffs or coastal plains, and thus are accessible to any metropolitan resident. The additional recommendation in their favour is that they may be appreciated by the "man who runs," and depend not for their understanding on laborious observation and skilled laboratory research. A wonderful charm is thus found to invest our characteristic scenery, since ability to trace the antecedent stages of the more prominent "facts of form" in a landscape cannot but conduce to the pleasure of contemplating sights at once noble and beautiful from the purely emotional point of view. The consideration of the control of population by the great uplift, the slight movements of later drowning, the profound cañons of the Upper Hawkesbury, the thievish propensities of that stream, the barren sandstone and mural sea-fronts of Sydney, also afford delightful cogitational exercises and illustrate the utter insignificance of man, the reflective, when opposed to natural activities.

\section{DESCRIPTION OF PLATES XXXIX.-XLIV.}

Plate xxxix.-Ideal Sections across the Blue Mountains during various Cycles.

Fig. a.-Jenolan Plain at close of Cycle.

Fig. b. - Jenolan Plain after elevation.

Fig. c.-Blue Mountain Plain at close of Cycle.

Fig. d.-Blue Mountain Plain after elevation.

Fig. e.-Lithgow Plain at close of Cycle.

Fig. f.-Lithgow Plain after elevation.

Fig. g.-Present contour illustrating insignificance of denudation during cañon cycle compared with that of Plateau periods.

Plate xl.-Govett's Leap, illustrating cañon-formation in alternating hard and soft layers of rock. Photo by A. E. Dyer.

Plate xli.-Valley of Grose, illustrating denudation during Cañon Cycle. 
Plate xlii.-Pittwater (Lower Hawkesbury), illustrating drowned valleys. Post-Tertiary subsidence. Photo by A. E. Dyer.

Plate xliii.-View of the Lithgow Peneplain, showing the cañon cut by the Port Hacking River, and the later drowning of the same. Photo by A. E. Dyer.

Plate xliv.-Map of Sydney district, showing extent of recent alluvium, deposited during recent subsidence and exposed by more recent elevation. Drawn by M. Morrison.

The stippled area shows the area occupied by recent alluvium as mapped by Mr. M. Morrison.

The area indicated by hatching shows recent alluvium mapped by Prof. David.

The influence of a current from the South is shown by the characteristic disposition of the Narrabeen type of bar. 


\section{$2 \mathrm{BHL}$ Biodiversity Heritage Library}

Andrews, E. C. 1904. "Notes on the geography of the Blue Mountains and Sydney district." Proceedings of the Linnean Society of New South Wales 28, 786-825. https://doi.org/10.5962/bhl.part.26364.

View This Item Online: https://www.biodiversitylibrary.org/item/30143

DOI: https://doi.org/10.5962/bhl.part.26364

Permalink: https://www.biodiversitylibrary.org/partpdf/26364

\section{Holding Institution}

MBLWHOI Library

\section{Sponsored by}

MBLWHOI Library

\section{Copyright \& Reuse}

Copyright Status: NOT_IN_COPYRIGHT

This document was created from content at the Biodiversity Heritage Library, the world's largest open access digital library for biodiversity literature and archives. Visit BHL at https://www.biodiversitylibrary.org. 